\title{
BIODIVERSITY AND DISTRIBUTION OF ISOPODA AND POLYCHAETA ALONG THE NORTHWESTERN PACIFIC OCEAN AND THE ARCTIC OCEAN
}

\author{
Hanieh Saeedi ${ }^{1 *}$, Angelika Brandt ${ }^{1,2}$, Nils L. JACObSEN ${ }^{2}$ \\ ${ }^{1}$ Senckenberg Research Institute and Natural History Museum; Department of Marine Zoology, \\ 60325 Frankfurt am Main, Germany \\ ${ }^{2}$ Goethe University Frankfurt, Institute for Ecology, Diversity and Evolution, 60438 Frankfurt am \\ Main, Germany
}

*Corresponding author: Hanieh Saeedi, hanieh.saeedi@senckenberg.de

\begin{abstract}
The northwestern Pacific Ocean is one of the hotspots of species richness and one of the high endemicity areas of the World Ocean. However, large-scale biodiversity patterns of major deep-sea taxa such as Isopoda and Polychaeta are still poorly studied. The goal of this research is to study the distribution, biodiversity, and community composition of Isopoda and Polychaeta (including Siboglinidae and Echiura) across the northwestern Pacific Ocean and the adjacent Arctic Ocean. The study area was divided into equal-sized hexagonal cells (c. 700,000 $\mathrm{km}^{2}$ ), ecoregions, $5^{\circ}$ latitudinal bands, and $200 \mathrm{~m}$ depth intervals as unit of analysis. Our results revealed that the area around the Philippines and the Laptev Sea had the highest isopod and polychaete's species richness compared to the other geographic regions of our study, with a latitudinal decline of species richness in shallow waters in both taxa. In the deep sea, maximum species richness increased towards the temperate latitudes. Gamma species richness (number of species per $200 \mathrm{~m}$ depth interval) also declined with depth. Rarefied species richness of isopods peaked around $5000 \mathrm{~m}$ depth. Rarefaction curves demonstrated a great potential for undiscovered richness across $5^{\circ}$ latitudinal bands and depth intervals. In shallow waters, polychaetes with a pelagic larval phase had a wider distribution range compared to brooding isopods, but, in the deep sea, isopods had slightly wider distribution ranges compared to polychaetes. These results thus demonstrated that shallow water taxa with pelagic larvae and polychaete species with a wide vertical distribution range could potentially invade higher latitudes, such as species from the Northwest Pacific invading the Arctic Ocean under the rapid climate change and catastrophic reduction of sea ice cover. These changes might dramatically change the benthic communities of the Arctic Ocean and management of such should take an adaptive approach and apply measures that take potential extension and invasion of species into account.
\end{abstract}

Key words: Biodiversity, Northwest Pacific Ocean, Arctic Ocean, Isopoda, Polychaeta

The northwestern Pacific Ocean (NWP) extends from the Equator in the south to the Arctic Ocean (AO) in the north, and from Asia and Australia in the west to $180^{\circ}$ longitude in the east. The NWP is characterized by many heterogeneous habitats and numerous oceanic islands and deep-sea trenches (Saeedi and Brandt 2020a; Saeedi et al. 2020). The tropical and subtropical areas of the west Pacific include the Indo-Australian Archipelago and host the highest number of marine species in the World Ocean (Renema et al. 2008; Saeedi et al. 2019b)

The bordering AO has an average depth of $987 \mathrm{~m}$ (Ostenso 1962). It is strongly influenced by the nutrient-rich water that is flowing through the Bering Strait (Woodgate and Aagaard 2005). Estimates of annual primary production in the northern Bering and the southern Chukchi Seas are very high, with an average of $470 \mathrm{~g} \mathrm{C} \mathrm{m}^{-2} \mathrm{y}^{-1}$ (Springer and McRoY 1993; Sakshaug 2004; Grebmeier et al. 2006). The Bering and Chukchi Sea shelves are among the largest shelf areas worldwide hosting a rich benthic food web, which in turn supports benthic-feeding predators (Grebmeier et al. 2006).

Isopoda are a crustacean order in the superfamily Peracarida with $>10,000$ species (Westheide and Rieger 1996). They are among the most common taxonomic groups in the World Ocean and are major contributors to the deep-sea diversity (Golovan et al. 2013). The suborder Asellota is predominant below $200 \mathrm{~m}$ depth. In some cases, isopod samples from 
deep-sea basins mostly consist of Asellota specimens (Brandt et al. 2004; Kaiser et al. 2009). One synapomorphic structure for all Peracarida including isopods is the marsupium, a brood chamber in which the females carry their offspring (Westheide and Rieger 1996; Saeedi and Brandt 2020a). After hatching, the isopods are in an early juvenile stage (manca) when they stay inside the marsupium (Westheide and Rieger 1996; Saeedi and Brandt 2020a). Usually, the isopods leave the brood chamber during the second manca stage (Wägele 1989). Thus, isopods are effectively missing a pelagic larval phase which might result in lower dispersal capabilities compared to taxa with a pelagic larval phase (Siegel et al. 2003).

Polychaeta is a class in the phylum Annelida. In this study, we refer to "Polychaeta" because the term has been widely used in the available literature. To date, $>12,000$ polychaete species have been recorded (Read and Fauchald 2020). Polychaetes are a very abundant taxon and occur in almost any marine benthic habitat feeding on deposited organic matter and microfauna enriching the food web (Hessler and JuMARS 1974; Fauchald 1983; Saeedi and Brandt 2020a). Polychaetes have a great diversity of developmental modes, often fertilized externally by releasing both eggs and sperms into the water column; thus, most Polychaeta larvae are planktotrophic (Fauchald 1983; Wilson 1991).

Pelagic larvae can be divided into planktotrophic larvae and lecithotrophic larvae, the former being the most common strategy for benthic invertebrates which implies feeding on phytoplankton and/or zooplankton (Wilson 1991; Levin 2006). Planktonic larval durations (PLD) range from just a few hours to multiple months (Carson and Hentschel 2006; Shanks 2009). A positive correlation between larval duration and dispersal distance has been recorded (Siegel et al. 2003; Shanks 2009). Larval behavior is important to consider regarding dispersal capabilities (Krug and Zimmer 2004). Species with a pelagic larval phase have the advantage that they can reach areas of favorable conditions more easily than brooders (Pechenik 1999), which might reduce fluctuations in adult populations (Eckert 2003). Brood protection, on the contrary, can offer security in terms of shelter and food availability (Levin and Bridges 1995). These attributes might be especially favorable in the food-limited deep-sea ecosystems (Bush et al. 2012). However, the global and regional distribution and diversity patterns of isopods and polychaetes should be studied further to enable us to better compare the dispersal abilities of these two taxa.

It is generally assumed that species richness for all marine species including isopods and polychaetes peaks in the Tropics and decreases towards higher latitudes (Rex et al. 2000; Brown 2014; Valentine and Jablonski 2015). However, recent studies have shown that latitudinal global species richness pattern is bimodal, not only decreasing with latitude and depth, but also decreasing at the Equator (Saeedi and Costello 2012; Costello and Chaudhary 2017; Saeedi et al. 2017b; Saeedi and Costello 2019). In the deep sea, maximum species richness is recorded at higher latitudes $\left(30-50^{\circ} \mathrm{N}\right.$; (McClain et al. 2012; Woolley et al. 2016; Saeedi et al. 2017b)). Species richness in shallow waters correlates positively with temperature (Tittensor et al. 2010; Chaudhary et al. 2017; Costello and Chaudhary 2017), whereas species richness in the deep sea is more likely influenced by chemical energy and food availability (Brandt et al. 2015; Brandt and Malyutina 2015; Woolley et al. 2016; Yasuhara and Danovaro 2016; Barroso et al. 2018; Golovan 2018; Saeedi et al. 2019a). Considering global climate change and its impacts on distributions of marine species, further investigating the main drivers of species distributions and richness should be prioritized.

The NWP and AO are experiencing rapid climate change; consequently, local species might experience a northward and southward distribution range shift (Simões et al. 2021). The latitudinal and bathymetric species-richness gradients, as well as their causes, need to be (re)examined in these areas. An understanding of present distributional patterns and their potential drivers is imperative to predicting future changes and their consequences. An informational basis is necessary for any conservational work or the implementation of Marine Protected Areas (MPA). Saeedi et al. (2019b) already investigated potential drivers of marine species richness in the NWP and the AO, but did not include the important role of dispersal abilities of different taxa as a driver of species richness patterns in those areas (Saeedi et al. 2019b; Saeedi et al. in press). In addition, studies of the relationship between developmental mode and distribution of marine species are rare (Mileikovsky 1971; Krug and Zimmer 2004). The goal of this study is thus to (1) analyze the latitudinal and bathymetric distribution of Polychaeta and Isopoda and identify hotspots of species richness, (2) compare species 
distributions of Isopoda and Polychaeta, and (3) discover if Polychaeta with a pelagic larval phase have wider distributions compared to Polychaeta with no pelagic larval phase and brooding Isopoda.

\section{Methods}

Study area and data preparation

The study area included large portions of the NWP and the adjacent $\mathrm{AO}$ at latitudes of $0-90^{\circ} \mathrm{N}$ and longitudes of $100-180^{\circ} \mathrm{E}$. Most records used in this study were extracted from the Ocean Biodiversity Information System (OBIS) and the Global Biodiversity Information Facility (GBIF). We also drew data from four Russian-German and German-Russian benthic deep-sea expeditions in the NWP (Malyutina and Brandt 2013; Brandt and Malyutina 2015; Malyutina and Brandt 2018; Saeedi et al. 2019e; Saeedi and Brandt 2020b). Records were collected by a great variety of sampling methods (Saeedi et al. 2019e; Saeedi and Brandt 2020b). The gear deployed during four benthic deep-sea expeditions included CTD, MUC (multicorer); GKG (giant box corer); EBS (epibenthic sledge); AGT (Agassiz Trawl), BT (bottom trawl) (Brandt and Malyutina 2014), BC (box corer) (Brandt et al. 2010), and PN (plankton net) (Chernyshev and Polyakova 2018). Standardized methodology was used for their deployment during all expeditions for reasons of comparison (Brandt and Malyutina 2014).

Data were merged and cleaned following Saeedi et al. (2019a). Records were checked for reliability with the R package "robis" (Provoost and Bosch 2020); doubtful coordinates were either corrected (e.g., when longitude and latitude were switched), or were removed (e.g., in the case of fossil records; (Saeedi et al. 2019b; Saeedi et al. 2019d)). All records were taxon-matched against the World Register of Marine Species (WoRMS). Old taxonomy was updated, and unconfirmed matches were crosschecked and incorporated into the dataset. Following the WoRMS taxonomy backbone for polychaetes, Siboglinidae and Echiura were included, but Sipunculas were not.

After these steps, the dataset consisted of 6716 records, of which 5328 records were Annelida and 1388 records were Arthropoda. Table S1 summarizes percentages of the records and available depth information for shallow water and deep sea in the NWP and AO (Table S1): 1066 species from 105 families were represented in the dataset. All records were classified as either shallow-water $(0-500 \mathrm{~m})$ or deep-sea
$(>500 \mathrm{~m})$ records, based on the World Register of Deep-Sea Species (WoRDSS; (Glover et al. 2021)). The reason for this classification is the small variability in physical parameters over different seasons and the negligible effect of sunlight on organisms at depths below $500 \mathrm{~m}$.

Information about presence of a pelagic larval phase was extracted from the literature and WoRMS, and added to the dataset for polychaetes. In addition to actual information available, an estimation method was used (Carson and Hentschel 2006): when $\geq 80 \%$ of a genus or family shared the same developmental mode, that mode was assumed for other species in that group. From a total of 736 polychaete species, 321 were classified as having a pelagic larval phase according to WoRMS and other literature (Fauchald 1983; Wilson 1991; Bhaud 1998; Carson and Hentschel 2006; Shanks 2009; Kędra et al. 2013; Read and Fauchald 2020) which corresponds to 2401 records, out of a total of 5328 records.

\section{Data analysis}

For data analysis and visualization, we used $\mathrm{R}$ 3.6.2 (R Core Team, 2020). The packages readxl (Wickham et al. 2019), tidyr (Wickham and Henry 2020), dplyr (Wickham et al. 2021), and ggplot2 (Wickham 2016) were employed for importing, cleaning, manipulating, and plotting the data. With the help of the sf package (Pebesma 2018), we created a map of the study area with an overlaying hexagonal grid. Each hexagonal cell covered roughly $700,000 \mathrm{~km}^{2}$; the study area was also divided into ecoregions to provide better insights for conservational planning. These ecoregions were taken from the Marine Ecoregions of the World (MEOW) polygon layer (Spalding et al. 2007). To study patterns of latitudinal and bathymetric distribution, the study area was divided into $5^{\circ}$ latitudinal bands and $200 \mathrm{~m}$ depth intervals.

Sampling effort, species richness, and rarefied species richness ES15 (see below) were calculated for each hexagonal cell, ecoregion, $5^{\circ}$ latitudinal band, and $200 \mathrm{~m}$ depth interval. Using an occurrence table, sampling effort was examined. Alpha species richness (species richness per hexagonal cell) and gamma species richness (species richness per $5^{\circ}$ latitudinal band) were calculated with a presence/ absence matrix. The rarefaction method (ES15) was employed to account for sampling bias (Saeedi et al. $2019 b$ ). It repeatedly re-samples 15 randomly chosen records from all records available and calculates 
(a)

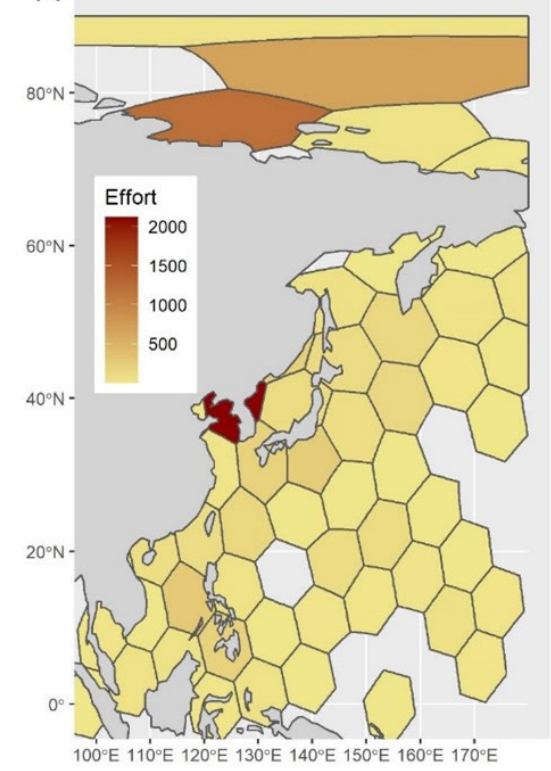

(b)

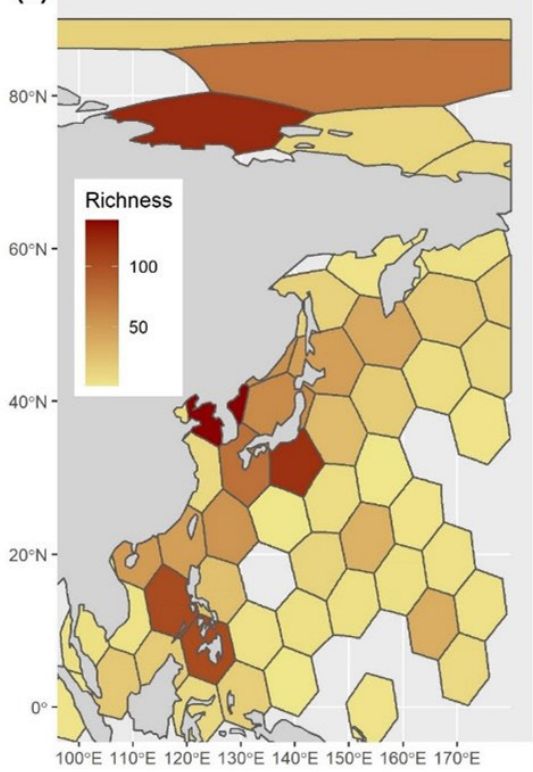

(c)

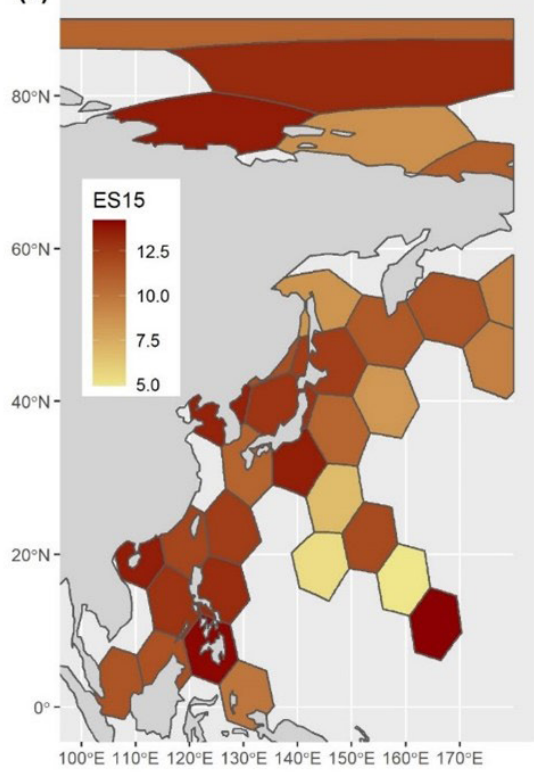

Figure 1: Biodiversity patterns across all taxa; (a) Sampling effort (number of distribution records), (b) alpha species richness (number of species per hexagon), and (c) ES15 (expected number of species) for both Isopoda and Polychaeta in the NW Pacific and the Arctic Ocean. Hexagon cell size is $700,000 \mathrm{~km}^{2}$. The areas with no hexagons had zero values.

the average species number per 15 records (Oksanen et al. 2019). A sample size of 15 was chosen over a sample size of 50, because the number of distribution records at a site needs to be higher than the chosen sample size in order to get a rarefied result. At many stations, the number of distribution records were too low for a sample size of 50. The function "rarefy" from the "vegan" R package Oksanen et al. 2019) was used for the rarefaction method.

The rarefaction method (ES15) was also employed to create rarefaction curves. Rarefied expected number of species shows the number of species in relation to the number of samples, by a random selection of samples along the study area. When a rarefaction curve reaches an asymptote, it implies that most or all of the species in a given area have been found. If the curve does not show a plateau, more sampling is needed (Chiarucci et al. 2008; Oksanen et al. 2019).

All isopod and polychaete records were grouped into suborders. Suborder was chosen as a unit of comparison because it enabled informative comparisons. Violin plots were created based on the suborders to study community composition and density distribution ranges of isopods and polychaetes in shallow waters and in the deep sea. A hierarchical cluster analysis was performed to study similarity and difference among ecoregions. Ordinary bootstrap resampling (BP) and multiscale bootstrap resampling
(AU) were handled by the function "pvclust" of the package (Suzuki and Shimodaira 2019)(Suzuki et al., 2019).

\section{RESULTS}

\section{Distribution and diversity}

Overall, the highest sampling effort (i.e., number of records) was recorded around South Korea based on both hexagons and ecoregions plots of isopods and polychaetes (Fig. 1; Fig. S1-S20). Alpha species richness peaked around South Korea, the Philippines, the Central Kuroshio Current region south of Japan, and in the Laptev Sea (Fig. 1; Fig. S1-S20). Rarefaction (ES15) showed that highest species richness was around the Philippines, Sea of Japan, Yellow Sea, and the AO (Fig. 1).

Isopod species had a narrower range compared to polychaete species in both shallow water and deep sea (Fig. 2; Fig. 3; Fig. S3-S6). The distribution percentages for isopods were $55.7 \%$ overall, $42.6 \%$ in shallow waters, and $29.5 \%$ in the deep sea. Deep-sea sampling effort for isopods was highest in the Oyashio Current region (Fig. S4). Species richness and ES15 values were higher around the Kuril-Kamchatka Trench, in the Oyashio Current region, and in the AO, compared to other regions (Fig. S4).

Polychaeta were present in $83.6 \%$ of all hexagons in the study area (Fig. 3; Fig. S5-S6). In shallow waters, this number was reduced to $77.1 \%$, and 
(a)

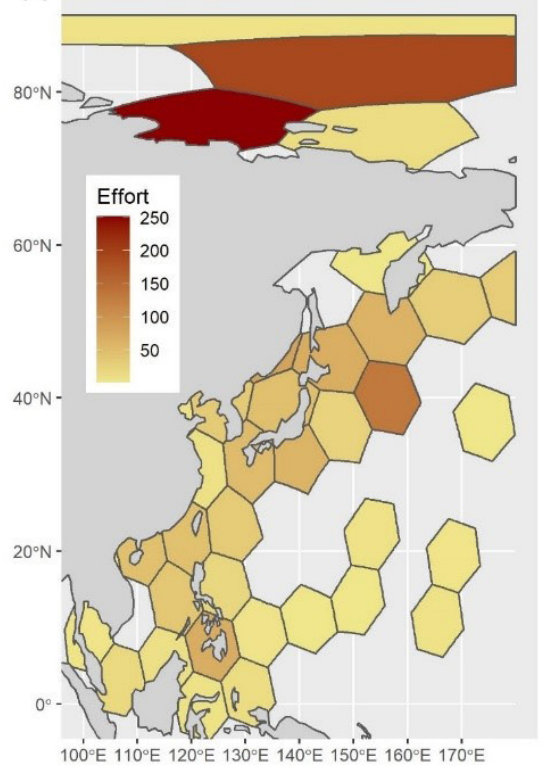

(b)

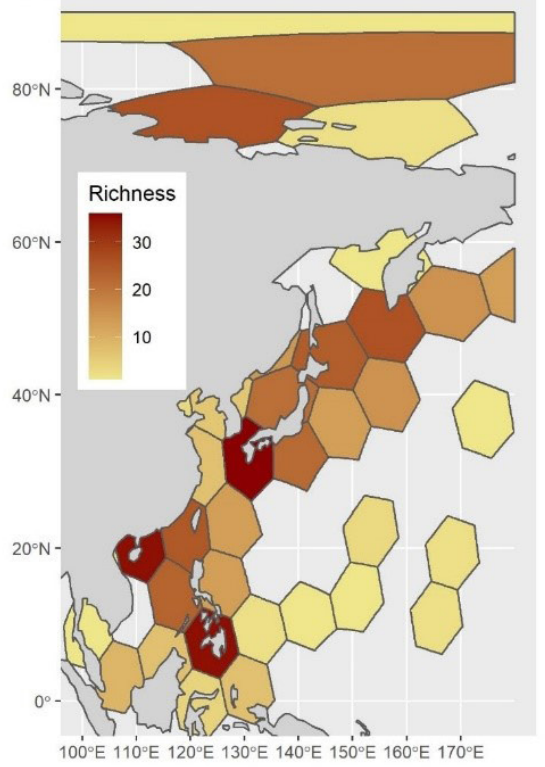

(c)

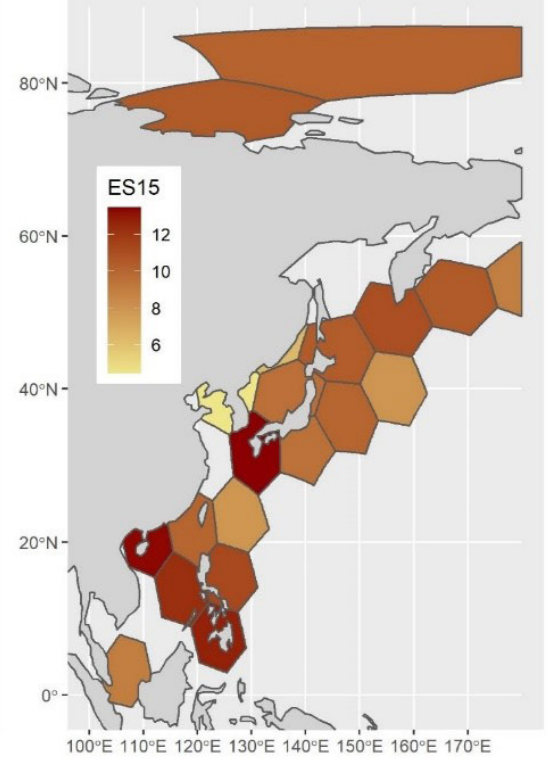

Figure 2: Biodiversity patterns of all Isopoda; (a) Sampling effort (number of distribution records), (b) alpha species richness (number of species per hexagon), and (c) ES15 (expected number of species) for all Isopoda in the NW Pacific and the Arctic Ocean. Hexagon cell size is $700,000 \mathrm{~km}^{2}$. The areas with no hexagons had zero values.

(a)

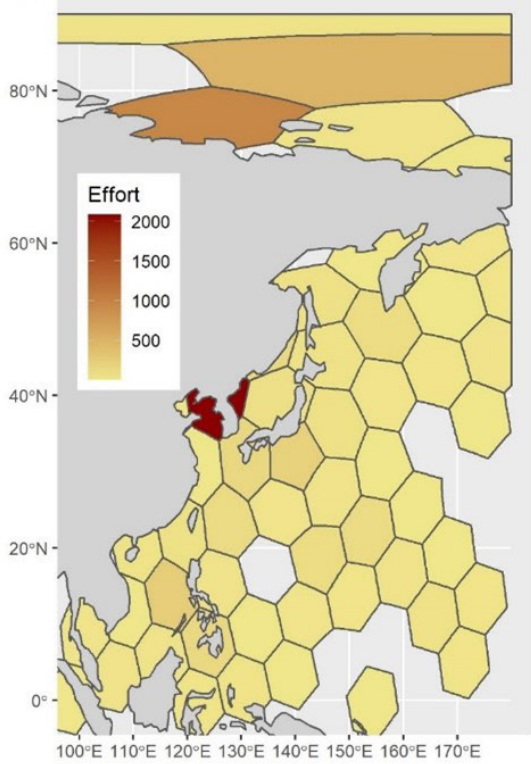

(b)

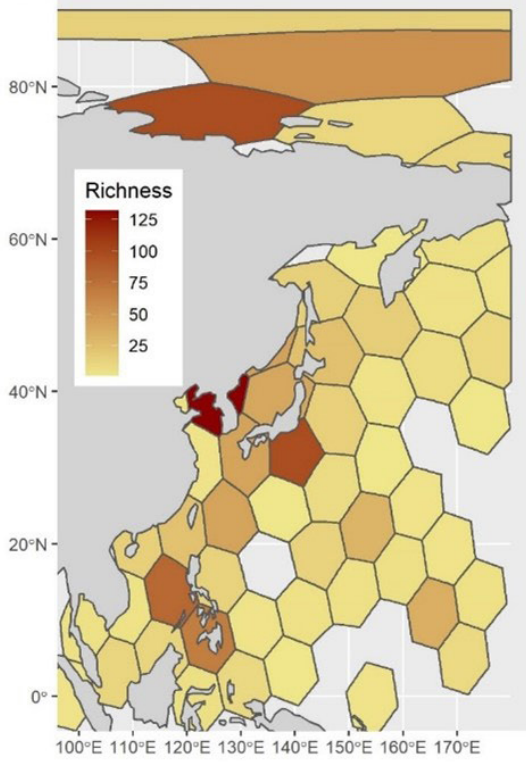

(c)

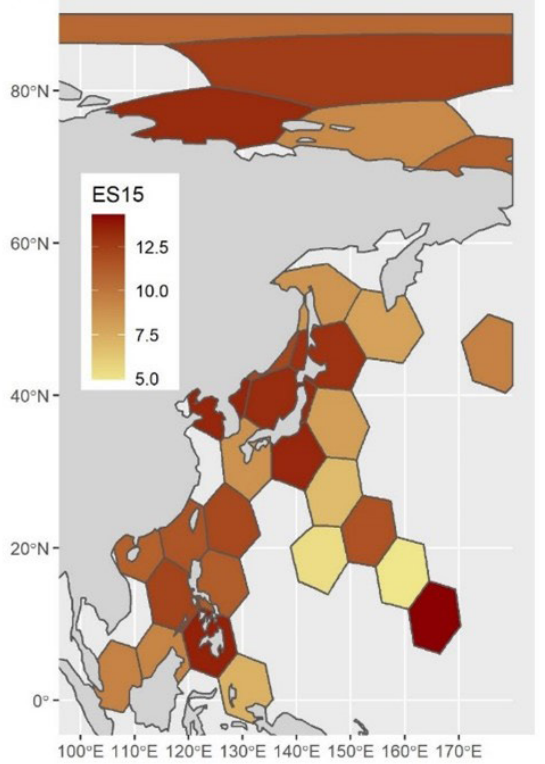

Figure 3: Biodiversity patterns of all Polychaeta; (a) Sampling effort (number of distribution records), (b) alpha species richness (number of species per hexagon), and (c) ES15 (expected number of species) for all Polychaeta in the NW Pacific and the Arctic Ocean. Hexagon cell size is $700,000 \mathrm{~km}^{2}$. The areas with no hexagons had zero values.

in the deep sea to $42.6 \%$. However, in the deep sea, polychaetes with a pelagic larval phase were only present in $24.6 \%$ of all hexagons. Polychaetes with a known pelagic larval phase also had wider distribution overall (73.8\% of all hexagons) and in shallow waters $(65.6 \%$ of all hexagons) compared to isopods. In the deep sea, sampling effort and alpha species richness were highest in the Laptev Sea (Fig.
S6). ES15 values were highest in the Laptev Sea and around the southern point of the Philippines. Because of the scarce amount of deep-sea records, rarefaction worked only for a small number of hexagons, so no clear pattern was observable.

Polychaetes with a known pelagic larval phase showed distribution and diversity patterns similar to those of polychaetes overall (Fig. S7). However, 

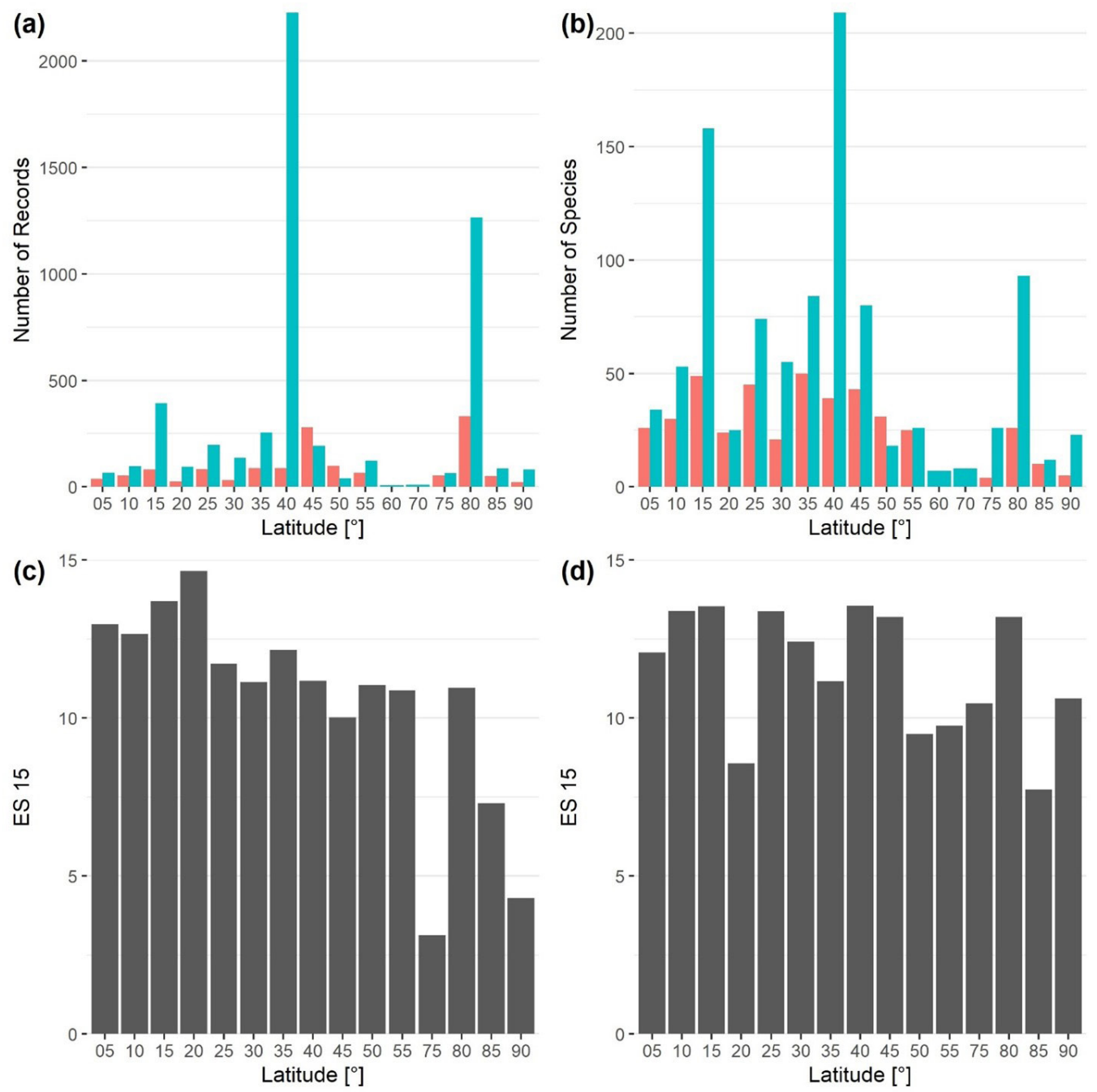

Figure 4: Latitudinal distribution and diversity of Isopoda and Polychaeta in the NW Pacific and the Arctic Ocean; (a) sampling effort (number of distribution records) and (b) gamma species richness (number of species per $5^{\circ}$ latitudinal band) for Isopoda (in red) and Polychaeta (in blue); ES15 values (expected number of species) for (c) Isopoda and (d) Polychaeta.

species richness and ES15 patterns in polychaetes with an unknown pelagic larval phase showed slight differences compared to polychaetes with a known pelagic larvae and overall polychaetes (Fig. S7-S10). Polychaetes with unknown pelagic larvae showed higher species richness in the AO as well the Sea of Japan and the Yellow Sea (Fig. S8). However, polychaetes with known and unknown pelagic larvae still had a broad distribution, and hotspots of sampling effort and species richness were identical. Since less data were available from the deep sea, the rarefaction method failed in more hexagons and ecoregions than before (Fig. S10). Nevertheless, ES15 hotspots were still present in the same locations.

\section{Latitudinal gradients}

Between the latitudes of $55^{\circ}$ and $75^{\circ} \mathrm{N}$, few or no records were available in light of less or minimum available ocean area (Fig. 4; Fig. S21). Sampling effort was highest at latitudes $40^{\circ}$ and $80^{\circ} \mathrm{N}$. Gamma species richness showed two peaks: one at $15^{\circ}$ and another one at $40^{\circ} \mathrm{N}$. ES15 values were highest at latitudes $5-10^{\circ} \mathrm{N}$, and were lowest at latitudes $20^{\circ}$ and $75^{\circ} \mathrm{N}$ (Fig. 4; Fig. S22). Values for the $\mathrm{AO}$ were slightly lower than those for the NWP.

Most of the records at $40^{\circ} \mathrm{N}$ had missing depth information (Table S1), which is why this peak disappeared when categorizing records by depth. In shallow waters, highest sampling effort was at $80^{\circ} \mathrm{N}$. For depths above $200 \mathrm{~m}$, gamma species richness was highest at $15^{\circ}$ and $80^{\circ} \mathrm{N}$. Also, a decline of species richness is visible towards higher latitudes, and with a dip near the Equator. In shallow waters, a dip at $20^{\circ} \mathrm{N}$ in rarefaction values was visible, with slightly lower than average levels at $50^{\circ} \mathrm{N}$ and at $\mathrm{AO}$ latitudes (Fig. S23). In the deep sea, sampling effort was 
highest at latitudes $45^{\circ}$ and $80^{\circ} \mathrm{N}$. Deep-sea gamma species richness was highest at $45^{\circ}$ and $80^{\circ} \mathrm{N}$. Highest deep sea ES15 values were recorded at latitudes $15^{\circ}, 40^{\circ}$, and $80^{\circ} \mathrm{N}$, whereas lowest values were at $20^{\circ}, 30^{\circ}$, and $85^{\circ} \mathrm{N}$ (Fig. S24).

For isopods, in shallow waters, sampling effort peaked at $80^{\circ} \mathrm{N}$ (Fig. S25). Gamma species richness decreased towards higher latitudes, with a small dip near the Equator and a peak at latitude $80^{\circ} \mathrm{N}$. In shallow waters, ES15 values were higher in the tropical zone, with peaks $35-45^{\circ}$ and $80^{\circ} \mathrm{N}$, compared to temperate and cold zones. Deep-sea sampling effort peaked at $45^{\circ}$ and $80^{\circ} \mathrm{N}$ (Fig. S26). Gamma species richness was highest between $40^{\circ}, 55^{\circ}$, and $80^{\circ} \mathrm{N}$.

In the rarefaction plot (Fig. S26, c), while showing a peak at $40^{\circ} \mathrm{N}$ and a drop at latitudes of $85^{\circ}$ $\mathrm{N}$ and greater, data were too few for a proper rarefaction estimation at many latitudinal bands in the deep sea. The rarefaction curve for all isopods per $5^{\circ}$ latitudinal band showed a high species count for the latitudes $15-40^{\circ} \mathrm{N}$ (Fig. S33). A flattening of the curve was clearly visible at latitudes $45^{\circ}$ and $80^{\circ} \mathrm{N}$. For AO latitudes, including $75^{\circ}, 85^{\circ}$ and $90^{\circ} \mathrm{N}$, species counts and sample sizes were minimal.

For polychaetes, shallow-water sampling effort was highest at latitude $80^{\circ} \mathrm{N}$, in addition to NWP latitudes of $15^{\circ}, 25^{\circ}$, and $35^{\circ} \mathrm{N}$ (Fig. S25). In shallow waters, species richness decreased with higher latitudes (except at $80^{\circ} \mathrm{N}$ ), and a dip was recorded near the Equator. The peak of gamma species richness was at $80^{\circ} \mathrm{N}$ latitude. Rarefaction produced a similar pattern to the ES15 values for all polychaete records. Deep-sea records showed a significant peak of sampling effort at $80^{\circ} \mathrm{N}$, and high values in the temperate and Arctic zones were also observed. Two peaks of gamma species richness were noticeable, at $45^{\circ} \mathrm{N}$ and $80^{\circ} \mathrm{N}$. ES15 values in the deep sea were lowest between latitudes $15^{\circ}$ and $35^{\circ} \mathrm{N}$, and at latitudes $55^{\circ}$ and $85^{\circ} \mathrm{N}$, compared to other latitudes.

\section{Bathymetric gradients}

From all 6716 records, $\sim 45 \%$ were from upper shallow depths above $200 \mathrm{~m}, \sim 18 \%$ in the deep sea; $\sim 37 \%$ were missing information about depth altogether. Around $71 \%$ of records were from the NWP and $\sim 29 \%$ from the AO. Isopoda and Polychaeta were both distributed over the whole depth range, from shallow waters to deep sea (Fig. S27-S28). Records came from the surface all the way to a depth of $10,170 \mathrm{~m}$ (the deepest record was a polychaete, Bathykermadeca hadalis (Kirkegaard, 1956), from
$10,170 \mathrm{~m}$ near the Philippines. For isopods, the deepest occurrence was at $9910 \mathrm{~m}$ from the same location, referred to Macrostylis galatheae Wolff, 1956. In the $\mathrm{AO}$, the deepest recorded specimen was from $4170 \mathrm{~m}$, of Aricidea (Aricidea) albatrossae Pettibone, 1957. Most records were from upper shallow waters above $200 \mathrm{~m}$. Almost half of isopods and $\sim 44 \%$ of polychaetes were found in this zone. Below the depth $200 \mathrm{~m}$, records decreased continuously, but peaked again around $600 \mathrm{~m}$. Many isopods were recorded around $5000 \mathrm{~m}$ in the NWP. Species richness values were correlated with number of records. ES15 had the highest values from depth $0 \mathrm{~m}$ to $600 \mathrm{~m}$, and then gradually declined below that depth, reaching its lowest value at $2800 \mathrm{~m}$ (Fig. S29-S30).

Rarefaction curves for both taxa showed similar patterns (Fig. S31-S36). The rarefaction analysis documented highest sample size and species count at $40^{\circ} \mathrm{N}$. The $40^{\circ} \mathrm{N}$ curve and the $80^{\circ} \mathrm{N}$ curve moved towards their maximum species count, while all others still showed potential for growth. Latitude $15^{\circ} \mathrm{N}$ was distinguished with a high species count for its sample size (Fig. S31). Highest sample sizes and species counts were in the range 0-200 m (upper shallow waters), followed by $400-600 \mathrm{~m}$ and $200-400 \mathrm{~m}$ (Fig. S32). A notable difference between isopods and polychaetes (except sample size and species count) was the depth range 5200-5400 m, where sample size was roughly equal to the $200-400 \mathrm{~m}$ range, with a flattened shape for isopods.

Isopods made up $\sim 21 \%$ of all records. Only $\sim 12 \%$ of isopod records had missing depth information. Shallow records were $\sim 49 \%$ and deep-sea records were $\sim 39 \%$ of the total. NWP records made up $67 \%$ and $\mathrm{AO}$ records constituted $33 \%$. Isopods were represented by 330 species. Of those, 302 species $(\sim 92 \%)$ were from the NWP, and $27(\sim 8 \%)$ from the AO; only one species was found in both areas. Around $45 \%$ of isopod species were classified as shallow-water species; $\sim 17 \%$ of isopods were present only in the deep sea, and $23 \%$ of isopods were eurybathic organism, found in both shallow waters and the deep sea.

Isopods are grouped into five suborders (Fig. 5); of 37 families, 34 could be assigned to a suborder. Asellota, Cymothoida, and Valvifera were dominant in the AO community, whereas Cymothoida was most prominent in the NWP, followed by Sphaeromatidea and Limnoriidea. Analyzing the bathymetrical distribution revealed that Asellota was by far the most common representative in shallow waters 
(a)
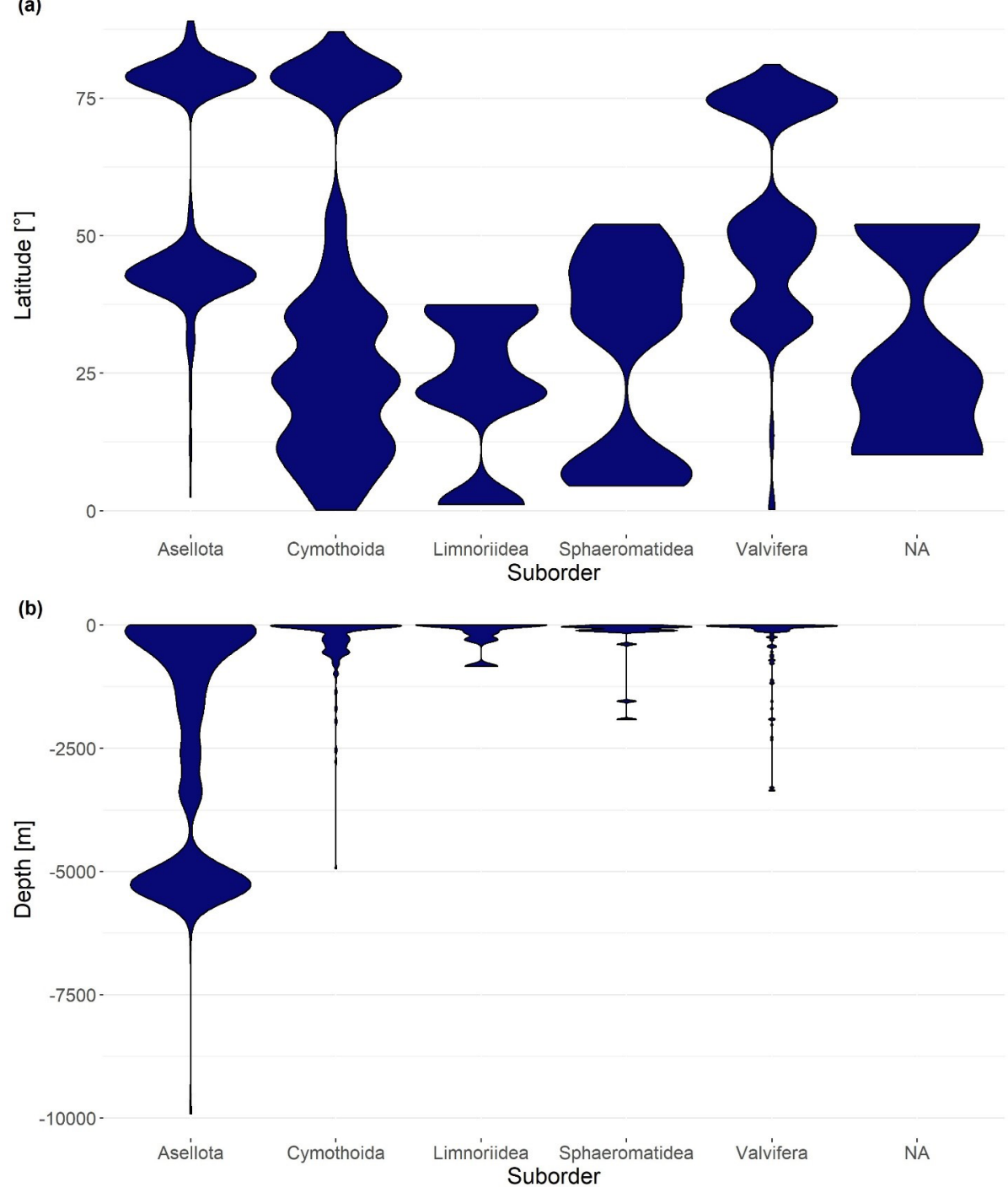

Figure 5: Violin plot representing the (a) latitudinal and (b) bathymetric distribution density range of Isopoda records for each suborder in the NW Pacific and the Arctic Ocean.

and in the deep sea. All other suborders were present in shallow waters, with few records from the deep sea. Asellota also had the widest distribution range (depthwise), with roughly twice the range of Cymothoida, which fell in second place.

For polychaetes, $\sim 80 \%$ of records were of polychaetes. Of those, over two thirds $(71.8 \%)$ were reported from the NWP, and the rest $(28.2 \%)$ from the AO. Polychaete records had more missing depth information $(43.8 \%)$ than isopod records. Around $43 \%$ of polychaete records were from shallow water, compared to nearly $13 \%$ from deep sea. The dataset included 736 polychaete species. Of those species, $624(\sim 85 \%)$ were found solely in the NWP; only 70 species $(\sim 10 \%)$ were from the AO. In total, 42 species $(6 \%)$ were present in both the NWP and the
AO. Half of the records were from shallow waters, and only $15 \%$ were from the deep sea; the rest had missing depth information. Of total records, 154 species $(21 \%)$ of Polychaeta occurred in both shallow water and deep sea. The violin plot for taxonomic composition of polychaete species by depth showed that Bonelliida was not the most common taxon in shallow waters (Fig. 6), but was the dominant taxon in the deep sea. While not having many records in the deep sea, Aphroditiformia had the widest distribution, followed by Bonelliida, compared to other taxa.

\section{Similarity cluster}

The cluster analysis of ecoregions revealed six distinct groups (Fig. 7); all had an AU value of $\geq 95$. The first cluster included the eastern Philippines and 

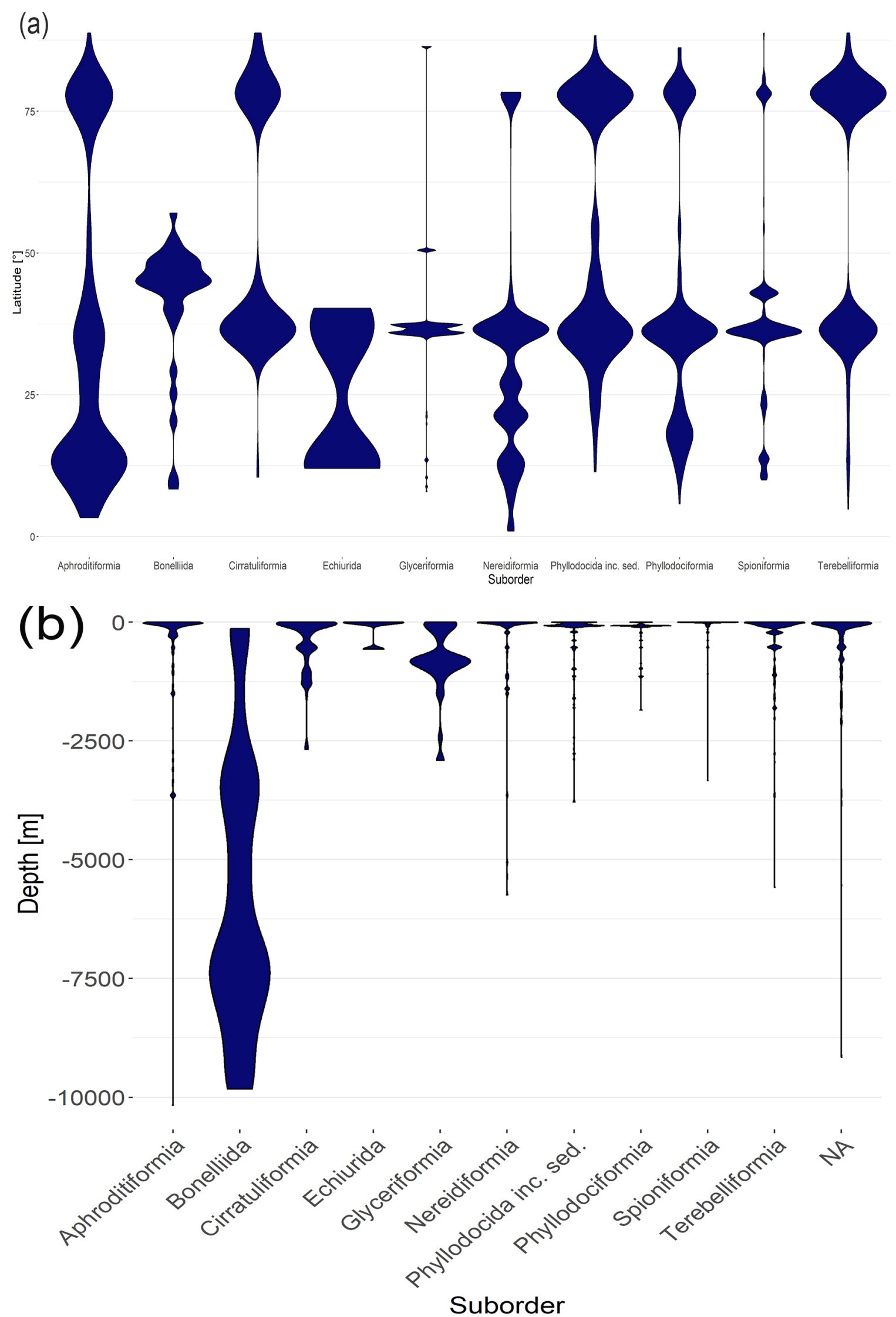

Figure 6: Violin plot representing the (a) latitudinal and (b) bathymetric distribution density range of Polychaeta records for each suborder in the NW Pacific and the Arctic Ocean. 
Palawan North Borneo $(\mathrm{AU}=100)$. The southern China ecoregion stood alone $(A U=95)$. The third cluster consisted of ecoregions from the $\mathrm{AO}$ and the Cold Temperate NWP (Sea of Okhotsk, Chukchi Sea, East Siberian Sea, Laptev Sea, Sea of Japan, and the Yellow Sea; AU =97). The first part of cluster number 4 included only ecoregions from the Central Indo-Pacific (South Kuroshio, Halmahera, Sulawesi Sea/Makassar Strait, Sunda Shelf/Java Sea, Gulf of Thailand, and Southern Vietnam), whereas the second part was more spread out, including ecoregions ranging from Central Indo-Pacific and Eastern Indo-Pacific to the Temperate Northern Pacific (Central Kuroshio Current, Marshall Islands, North-eastern Honshu, Mariana Islands, and Ogasawara Islands). Cluster $5(\mathrm{AU}=97)$ included mostly ecoregions from the Temperate Northern Pacific (East China Sea, Oyashio Current, Aleutian Islands and Kamchatka Shelf and Coast), plus two from the Central Indo-Pacific (West Caroline Islands and Northeast Sulawesi). Cluster 7 consisted only of ecoregions from the Central Indo-Pacific (Gulf of Tonkin, Malacca Strait, East Caroline Islands, and South China Sea Oceanic Islands; $\mathrm{AU}=96$ ).

\section{DisCUSSION \\ Distribution and diversity}

In this study, we used open-access data in combination with data from four Russian-German and German-Russian benthic deep-sea expeditions to the NWP. The open-access data were only available in English. The resulting dataset therefore suffered from taxonomic, language (i.e., no local languages), and geographic bias.

We documented high alpha species richness (number of species per hexagonal cell), as well as high ES15 values (expected species richness) for the area around the Philippines. This concentration was observed for both shallow waters and the deep sea. These findings are supported by earlier studies (Renema et al. 2008; Costello and Chaudhary 2017; Saeedi et al. 2019b). In fact, the Indo-Australian Archipelago (IAA) is considered as the most diverse region of the World Ocean (Renema et al. 2008; Chaudhary et al. 2016; Chaudhary et al. 2017; Saeedi et al. 2017a; Saeedi et al. 2017b). The past and present hotspots of marine species richness mark the locations of collisions between tectonic plates (Renema et al. 2008). During the early stage of plate collisions, new shallow-water habitats are created and new islands appear (Provoost and Bosch 2020). This

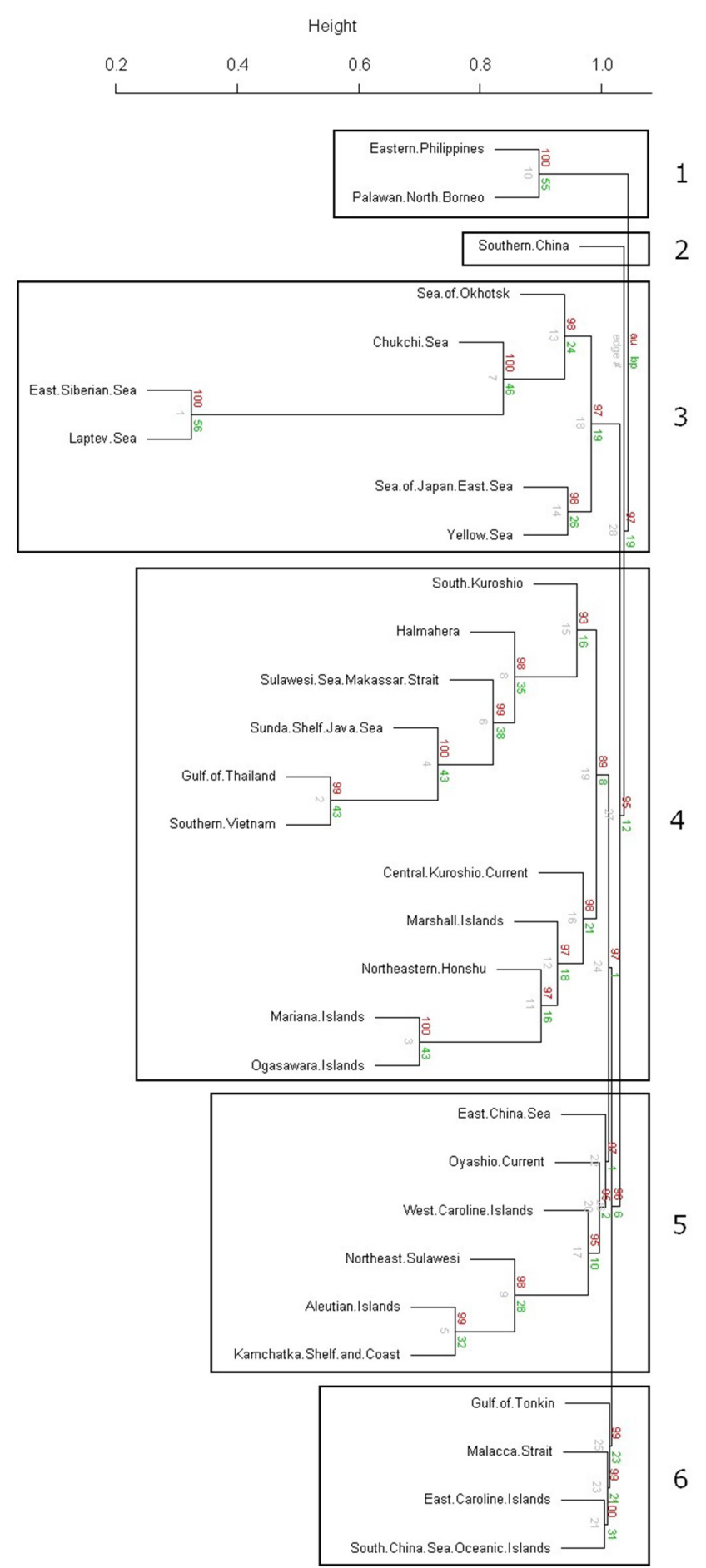

Figure 7: Cluster analysis (pvclust) of Isopoda and Polychaeta in ecoregions of the NW Pacific and the Arctic Ocean. The numbers above each edge show the probability of nodes below that edge occurring as a cluster in resampled trees, via ordinary bootstrap resampling (BP, green) or multiscale bootstrap resampling (AU, red); distance: correlation; cluster method: average. 
process results in altered ocean circulation, more heterogeneous habitats, and opportunities for isolation of populations, which all have been identified as driving factors of species richness (Jokiel and Martinelli 1992; Bellwood and Hughes 2001; Bellwood et al. 2005; Leprieur et al. 2016). Temperature has also been found to be significantly correlated with species richness (Tittensor et al. 2010; Costello and Chaudhary 2017; Saeedi et al. 2017b; Saeedi and Costello 2019; Saeedi et al. 2019c): higher temperatures can speed metabolism and mutation rates, which in turn may result in higher speciation potential (Costello and Chaudhary 2017), as well as allowing for a wider range of energetic lifestyles (Clarke and Gaston 2006). Our results also revealed hotspots of species richness in Isopoda and Polychaeta in convergence zones and areas of high temperature.

In addition to the Philippine hotspot of species richness in the NWP, we have also found species richness hotspots (alpha and ES15) in the AO for both Isopoda and Polychaeta. High alpha species richness values of marine species in the $\mathrm{AO}$ have been already reported in our previous study (Saeedi et al. 2019b). In particular, values of ES15 showed that the AO could be very rich if we account for sampling bias. As such, species richness in the AO might be higher than has been thought before, given lower sampling effort compared to other areas (Bodil et al. 2011; Saeedi et al. 2019b). This sampling gap is most likely the case for many other marine taxa, especially for deep-sea fauna.

For example, analysis of deep-sea isopod records here presented a high alpha species richness as well as and high ES15 value in the deep Kuril-Kamchatka Trench (KKT) area. Our results match earlier findings (Brandt and Malyutina 2015; Golovan et al. 2018). This high diversity in the deep sea of the KKT has been reported to be most likely correlated with food availability (Golovan et al. 2018). Golovan et al. (2018) reported that peracarid abundance and species richness increased with a high sediment organic carbon content. Compared to deep-sea isopods, deep-sea polychaetes did not show high alpha species richness in the KKT area in our study.

Alpha species richness was expected be highest in the IAA region in Polychaeta. Nonetheless, we found that polychaetes had highest alpha species richness in the Laptev Sea, in both shallow water and deep sea. Higher polychaete species richness in the AO compared to the NWP has been already reported by Saeedi et al. (2019b). Older studies reported gen- erally low AO species richness (Bilyard and Carey Jr 1980; Kupriyanova and Badyaev 1998), whereas recent studies revised species richness estimates upward (Sirenko 2001; Kędra et al. 2013). We suggest that the species richness in the AO is likely higher than expected before owing to low sampling effort.

\section{Dispersal and distribution}

In this study, we compared brooding isopods with polychaetes that have pelagic larval phases (including planktotrophic and lecithotrophic larvae), and polychaetes with unknown pelagic larvae. In shallow waters, polychaetes with pelagic larval phases had a wider distribution compared to brooding isopods. The distributions of polychaetes with pelagic larvae and those with unknown pelagic larvae did not differ markedly. Deep sea isopods had wider distributions compared to polychaete species. Previous work has shown that polychaetes with pelagic larval phases have significantly wider distributions compared to brooding isopods in shallow waters, which could be a function of the dispersal capabilities of the polychaete larvae (Grantham et al. 2003; Siegel et al. 2003).

Grantham et al. (2003) studied the dispersal potential of marine invertebrates. They found that planktotrophic polychaetes stayed an average of 57 days in the planktonic phase and could disperse tens or hundreds of kilometers. They also discovered that lecithotrophs stayed on average 7 days in the planktonic phase, and suggested a lower dispersal rate for this group (Grantham et al. 2003). Planktonic larval durations are reported to be correlated with dispersal distance (Shanks 2009), which typically ranges from $20-40 \mathrm{~km}$ for short PLDs and $>200 \mathrm{~km}$ for long PLDs (Siegel et al. 2003). Species with greater dispersal potential suggested a higher probability to reach areas of favorable conditions, as well as lower risk of extinction (Pechenik 1999; Eckert 2003).

One difference between the two studied taxa was that $\sim 5.7 \%$ of polychaete species were present in both NWP and the AO, but only $0.3 \%$ of isopod species were reported from both oceans. One possible explanation for this contrast might be the dispersal capabilities of the polychaete larvae (Grantham et al. 2003; Siegel et al. 2003), although it could result other influences, such as sampling bias and taxonomic expert bias.

In the deep sea; however, Isopoda had a wider distribution compared to Polychaeta with a pelagic larval phase. The possibly higher protection through 
brooding (Pechenik 1999) and active selection for favorable conditions (Hunt and Seibel 2000) might be responsible for this. Intuitively, one would assume that greater dispersal capabilities always result in a wider distribution range, but the following variables must be considered as well. Ecological niche-related constraints like temperature can limit the areas where larvae can survive (Verween et al. 2007; Talmage and Gobler 2011; Chaudhary et al. 2016; Saeedi et al. 2017b); ocean currents and turbidity influence dispersal of larvae significantly (Bhaud 1998; Bhaud 2000; Carson and Hentschel 2006)); and inter- and intraspecific competition and resistance to pollutants and microbes must also be considered (Economou 1991; Pechenik 1999; McEdward 2020).

The isopod suborder Asellota had by far the highest density in shallow waters, as well as in the deep sea. It has been recorded that the diversity of the suborder Asellota increases in some cases with depth, while the diversity of other isopod suborders decreases with depth (Saeedi and Brandt 2020a). In this study, the polychaete suborder Bonelliida had highest density in the deep sea, compared to other polychaete suborders. They have been described as a characteristic part of the fauna in the abyssal and hadal zones (Zenkevitch 1966), but information on these taxa is scarce and no recent studies are available.

Further research is necessary to understand the mechanisms of larval dispersal and their implications for distributions of adult organisms. Different methods of marking larvae could allow for direct measurement of larval dispersal, such as using artificial markers, environmental tags, or genetic markers (Thorrold et al. 2002; Cowen and Sponaugle 2009). Through these methods, dispersal distances can be observed, and larval trajectories can be estimated (Jones et al. 1999). In this way, it is possible to investigate the relationship between dispersal and distribution, as well as population connectivity. These factors must be considered in the design of effective marine reserves.

\section{Latitudinal gradients}

Species richness decreased towards higher latitudes in both isopods and polychaetes across the NWP and the AO. The this pattern, in combination with a dip near the Equator, has been reported to correlate with sea temperature (Chaudhary et al. 2016; Chaudhary et al. 2017; Saeedi et al. 2017b). Bivalve larvae, for example, could not stand temperatures $>28^{\circ} \mathrm{C}$, which led to higher embryo and larval mortality (Verween et al. 2007; Talmage and Gobler 2011). A clear northward shift of gamma species richness was observed in deep-sea isopods. Latitude $80^{\circ} \mathrm{N}$ had an ES15 value of $\sim 10$, and was therefore just as species-rich as the temperate latitudes.

A peak in species richness in temperate deep-sea latitudes has been found in other taxa (Rex et al. 2000). Since productivity in the deep sea is generally low (except for hydrothermal vent areas), input of particulate organic matter (POM) plays an important role as a driver of species richness (Woolley et al. 2016; Golovan 2018). Sediment heterogeneity has been shown to increase species richness, and is important to consider in the context of deep-sea habitats owing to the great number of deposit feeders that rely on organic detritus as a food source (Levin et al. 2001). Another important factor shaping deep-sea species richness is oxygen concentration (Levin and Gage 1998; Saeedi et al. 2020): Levin et al. (2001) stated that oxygen-depleted bottom water typically resulted in strongly reduced macrofaunal diversity. The same drivers of species richness, in both shallow waters and in the deep sea, must be considered when investigating polychaete distribution patterns.

As documented for isopods, polychaete species richness in shallow waters decreased at higher latitudes and increased towards temperate latitudes in the deep sea. Nonetheless, highest species richness, for shallow-water as well as deep-sea polychaetes, was recorded at latitude $80^{\circ} \mathrm{N}$. This result is consistent with our previous findings (Saeedi et al. 2019b), who attributed this effect to higher sampling and taxonomy efforts in that area. The lower species richness at latitudes $55-75^{\circ} \mathrm{N}$ and $\geq 85^{\circ} \mathrm{N}$ might be explained by the relatively little available ocean area.

\section{Bathymetric gradients}

In the present research, a clear decline in species richness from shallow waters to the deep sea was recorded in both isopods and polychaetes. Most samples were reported in depths above $200 \mathrm{~m}$, and were correlated with highest species richness values. Both isopod and polychaete species richness peaked again at a depth of $\sim 600 \mathrm{~m}$. Isopod sampling effort and species richness increased greatly a depth of $\sim 5000 \mathrm{~m}$. Most isopod records at this depth originate from the KuramBio expedition in 2012 (Brandt and Malyutina 2015). The peak around South Korea was not visible for records above or below $200 \mathrm{~m}$, meaning that these records had missing depth information. 
ES15 values for depths 5000-5600 m were comparable to ES15 value for depths $\sim 1000 \mathrm{~m}$. In general, species richness decreases with depth (Costello and Chaudhary 2017; Saeedi et al. 2019b). This linear decline of species richness with depth, in combination with peaks at $\sim 500 \mathrm{~m}$ and again at abyssal depths, has appeared in other studies of different taxa (Rex et al. 2005; Yasuhara et al. 2012; Jöst et al. 2019; Saeedi et al. 2020). Variability in species richness in relation to depth can be explained by heterogeneity of POM (Golovan et al. 2018), sediment and habitat (Levin et al. 2001), and oxygen concentration (Levin and Gage 1998; Levin et al. 2001; Saeedi et al. 2020).

\section{Cluster analysis}

Cluster analysis of the ecoregions revealed six significantly different groups of Isopoda and Polycheta distribution. The first consisted of Palawan North Borneo and the Eastern Philippines, which encompasses the ocean area directly around the Philippines and indicates a distinct community in this area. These finding are in agreement with earlier studies (Roberts et al. 2002; Saeedi et al. 2019b). The second cluster consisted only of the Southern China Sea, which was surprising in view of the great distance to cluster 6, which includes the Gulf of Tonkin and the South China Sea Oceanic Islands. Given their immediate geographic connection, higher similarity was expected. This distance could be explained by a high endemicity rate in benthic species, which has been reported for the Gulf of Tonkin (Saeedi et al. 2019b). Cluster number 3 revealed a high similarity between the Sea of Okhotsk and the Arctic Ocean, probably due to the waters that are flowing through the Bering Strait which heavily influence the AO (Woodgate and Aagaard 2005). The cluster analysis revealed the generally expected groups which were explained by rates of endemicity (Roberts et al. 2002; Saeedi et al. 2019b) and hydrological characteristics (Woodgate and Aagaard 2005).

\section{ConClusions}

The present research documented high species richness around the Philippines and in the Laptev Sea in Isopoda and Polychaeta. These values were coupled with high ES15 values, suggesting no high correlation between sampling bias and species richness in regards to the Philippines and to the AO. Latitudinal species richness in both Isopoda and Polychaeta decreased towards higher latitudes, in agreement with recent studies, such as declining species richness with latitude in shallow waters, an increase in species richness towards temperate latitudes in the deep sea, and the majority of species occurring in coastal depths. However, a peak in the expected number of species was observed for polychates in the $\mathrm{AO}$, highlighting the importance of sampling bias in geographic studies of specific taxa.

To conserve global biodiversity, we need to understand underlying mechanisms that operate at this scale. The present study demonstrated a fundamental need for higher sampling effort across all latitudes and depth intervals. AO species richness is suspected to be higher than appreciated previously. Thus, we advocate for increased sampling effort, with special consideration focus on the AO. The impact of larval dispersal on distributions of organisms should be integrated into the design of Marine Protected Areas. The information presented in this paper adds to the global picture of species richness patterns and functional biodiversity, which is necessary to prioritize areas for employing effective conservation efforts.

\section{DECLARATIONS \\ Ethics approval and consent to participate} Not applicable

Not applicable

\section{Consent for publication}

\section{Availability of data and materials}

The data used in this study retrieved from open-access databases including OBIS and GBIF (dataset citations are in doi: https://doi.org/10.1038/ s41598-019-45813-9) in combination with our own expedition data published in OBIS (doi: http://ipt. iobis.org/obis-deepsea/resource?r=beneficial deepsea\&amp; $v=1$ and doi: https:/www.gbif.org/dataset/24c56165-469b-426a-98bb-2cbdef596680). The cleaned dataset analyzed in this study, as well as the R scripts, are shared via Github ${ }^{1}$. Supplementary materials are available also ${ }^{2}$.

\section{Competing interests}

The authors declare that they have no competing interests.

https://github.com/haniehsaeedi/BIODIVERSITY-AND-DISTRIBUTION-OF-ISOPODA-AND-POLYCHAETA.

${ }^{2}$ http://hdl.handle.net/1808/32555. 


\section{Funding}

This paper was part of the "Biogeography of the NW Pacific deep-sea fauna and their possible future invasions into the Arctic Ocean project (Beneficial project)". Beneficial project (grant number 03F0780A) was funded by Federal Ministry for Education and Research (BMBF: Bundesministerium für Bildung und Forschung) in Germany.

\section{Authors' contributions}

HS developed the idea of the paper, contributed in running the analyses, and was a major contributor in writing the manuscript. NLJ developed the idea of the paper, ran the analyses, and was a major contributor in writing the manuscript. $\mathrm{AB}$ contributed in developing the idea and helped in writing the paper. All authors read and approved the final manuscript.

\section{Acknowledgements}

We would like to thank Laura Breitkreuz for the English proofreading of the manuscript. We would like to also thank the anonymous reviewers for their constructive comments, and the editor, Townsend Peterson, who has majorly edited the last version of this manuscript.

\section{REFERENCES}

Barroso, R., J. D. Kudenov, K. M. Halanych, H. Saeedi, P. Y. G. Sumida, and A. F. Bernardino. 2018. A new species of xylophylic fireworm (Annelida: Amphinomidae: Cryptonome) from deep-sea wood falls in the SW Atlantic. Deep Sea Research Part I: Oceanographic Research Papers 137:66-75.

Bellwood, D. R., T. Hughes, S. Connolly, and J. Tanner. 2005. Environmental and geometric constraints on Indo-Pacific coral reef biodiversity. Ecology Letters 8:643-651.

Bellwood, D. R. and T. P. Hughes. 2001. Regional-scale assembly rules and biodiversity of coral reefs. Science (New York, N.Y.) 292:1532-1535.

Bhaud, M. 1998. The spreading potential of polychaete larvae does not predict adult distributions; consequences for conditions of recruitment. Hydrobiologia 375:35-47.

Bhaud, M. 2000. Some examples of the contribution of planktonic larval stages to the biology and ecology of polychaetes. Bulletin of marine science 67:345-358.

Bilyard, G. R. and A. G. Carey Jr. 1980. Zoogeography of western beaufort sea polychaeta (Annelida). Sarsia 65:19-25.
Bodil, B. A., W. G. Ambrose, M. Bergmann, L. M. Clough, A. V. Gebruk, C. Hasemann, K. Iken, M. Klages, I. R. MacDonald, and P. E. Renaud. 2011. Diversity of the arctic deep-sea benthos. Marine Biodiversity 41:87107.

Brandt, A., W. Brökeland, S. Brix, and M. Malyutina. 2004. Diversity of Southern Ocean deep-sea Isopoda (Crustacea, Malacostraca) - a comparison with shelf data. Deep Sea Research Part II: Topical Studies in Oceanography 51:1753-1768.

Brandt, A., N. O. Elsner, M. V. Malyutina, N. Brenke, O. A. Golovan, A. V. Lavrenteva, and T. Riehl. 2015. Abyssal macrofauna of the Kuril-Kamchatka Trench area (Northwest Pacific) collected by means of a camera-epibenthic sledge. Deep Sea Research Part II: Topical Studies in Oceanography 111:175-187.

Brandt, A. and M. Malyutina. 2014. German-Russian deep-sea expedition KuramBio (Kurile Kamchatka Biodiversity Study)-results and perspectives.

Brandt, A., M. Malyutina, N. Majorova, A. Bashmanov, N. Brenke, T. Chizhova, N. Elsner, O. Golovan, C. Göcke, and D. Kaplunenko. 2010. The Russian-German deep-sea expedition (SoJaBio).

Brandt, A. and M. V. Malyutina. 2015. The German-Russian deep-sea expedition KuramBio (Kurile Kamchatka biodiversity studies) on board of the RV Sonne in 2012 following the footsteps of the legendary expeditions with RV Vityaz. Deep Sea Research Part II: Topical Studies in Oceanography 111:1-9.

Brown, J. H. 2014. Why are there so many species in the tropics? Journal of Biogeography 41:8-22.

Bush, S. L., H. J. Hoving, C. L. Huffard, B. H. Robison, and L. D. Zeidberg. 2012. Brooding and sperm storage by the deep-sea squid Bathyteuthis berryi (Cephalopoda: Decapodiformes). Journal of the Marine Biological Association of the United Kingdom 92:1629-1636.

Carson, H. S. and B. T. Hentschel. 2006. Estimating the dispersal potential of polychaete species in the Southern California Bight: implications for designing marine reserves. Marine Ecology Progress Series 316:105-113.

Chaudhary, C., H. Saeedi, and M. J. Castello. 2016. Bimodality of Latitudinal Gradients in Marine Species Richness. Trends in Ecology \& Evolution 31:670676.

Chaudhary, C., H. Saeedi, and M. J. Costello. 2017. Marine Species Richness Is Bimodal with Latitude: A Reply to Fernandez and Marques. Trends in Ecology \& Evolution 32:234-237.

Chernyshev, A. V. and N. E. Polyakova. 2018. Nemerteans from deep-sea expedition SokhoBio with description 
of Uniporus alisae sp. nov.(Hoplonemertea: Reptantia sl) from the Sea of Okhotsk. Deep Sea Research Part II: Topical Studies in Oceanography 154:121-139.

Chiarucci, A., G. Bacaro, D. Rocchini, and L. Fattorini. 2008. Discovering and rediscovering the sample-based rarefaction formula in the ecological literature. Community Ecology 9:121-123.

Clarke, A. and K. J. Gaston. 2006. Climate, energy and diversity. Proceedings. Biological sciences 273:22572266.

Costello, M. J. and C. Chaudhary. 2017. Marine biodiversity, biogeography, deep-sea gradients, and conservation. Current Biology 27:R511-R527.

Cowen, R. K. and S. Sponaugle. 2009. Larval dispersal and marine population connectivity. Annual review of marine science 1:443-466.

Eckert, G. L. 2003. Effects of the planktonic period on marine population fluctuations. Ecology 84:372-383.

Economou, A. N. 1991. Is dispersal of fish eggs, embryos and larvae an insurance against density dependence? Environmental Biology of Fishes 31:313-321.

Fauchald, K. 1983. Life diagram patterns in benthic polychaetes. Proceedings of the biological Society of Washington.

Glover, A. G., N. Higgs, and T. Horton. 2021. World Register of Deep-Sea species (WoRDSS). http://www. marinespecies.org/deepsea

Golovan, O. A. 2018. Desmosomatidae (Isopoda: Asellota) from the Kuril Basin of the Sea of Okhotsk: First data on diversity with the description of the dominant species Mirabilicoxa biramosa sp. nov. Deep Sea Research Part II: Topical Studies in Oceanography 154:292-307.

Golovan, O. A., M. Błażewicz-Paszkowycz, A. Brandt, L. L. Budnikova, N. O. Elsner, V. V. Ivin, A. V. Lavrenteva, M. V. Malyutina, V. V. Petryashov, and L. A. Tzareva. 2013. Diversity and distribution of peracarid crustaceans (Malacostraca) from the continental slope and the deep-sea basin of the Sea of Japan. Deep Sea Research Part II: Topical Studies in Oceanography 86:66-78.

Golovan, O. A., M. V. Malyutina, and A. Brandt. 2018. First record of the deep-sea isopod family Dendrotionidae (Isopoda: Asellota) from the Northwest Pacific with description of two new species of Dendromunna. Marine Biodiversity 48:531-544.

Grantham, B. A., G. L. Eckert, and A. L. Shanks. 2003. Dispersal potential of marine invertebrates in diverse habitats: ecological archives A013-001-A1. Ecological Applications 13:108-116.
Grebmeier, J. M., L. W. Cooper, H. M. Feder, and B. I. Sirenko. 2006. Ecosystem dynamics of the Pacific-influenced Northern Bering and Chukchi Seas in the Amerasian Arctic. Progress in Oceanography 71:331361 .

Hessler, R. R. and P. A. JuMARS. 1974. Abyssal community analysis from replicate cores in the central North Pacific. Pp. 185-209. Deep Sea Research and Oceanographic Abstracts. Elsevier.

Hunt, J. and B. Seibel. 2000. Life history of Gonatus onyx (Cephalopoda: Teuthoidea): ontogenetic changes in habitat, behavior and physiology. Marine Biology 136:543-552.

Jokiel, P. and F. Martinelli. 1992. The vortex model of coral reef biogeography. Journal of Biogeography:449-458.

Jones, G. P., M. Milicich, M. Emslie, and C. Lunow. 1999. Self-recruitment in a coral reef fish population. Nature 402:802-804.

Jöst, A. B., M. Yasuhara, C. L. Wei, H. Okahashi, A. Ostmann, P. Martínez Arbizu, B. Mamo, J. Svavarsson, and S. Brix. 2019. North Atlantic Gateway: Test bed of deep-sea macroecological patterns. Journal of Biogeography 46:2056-2066.

Kaiser, S., D. K. Barnes, C. J. Sands, and A. Brandt. 2009. Biodiversity of an unknown Antarctic Sea: assessing isopod richness and abundance in the first benthic survey of the Amundsen continental shelf. Marine Biodiversity 39:27-43.

Kędra, M., K. Pabis, S. Gromisz, and J. M. Węsławski. 2013. Distribution patterns of polychaete fauna in an Arctic fjord (Hornsund, Spitsbergen). Polar Biology 36:1463-1472.

Krug, P. J. and R. K. Zimmer. 2004. Developmental dimorphism: consequences for larval behavior and dispersal potential in a marine gastropod. The Biological bulletin 207:233-246.

Kupriyanova, E. K. and A. V. Badyaev. 1998. Ecological correlates of arctic Serpulidae (Annelida, Polychaeta) distributions. Ophelia 49:181-193.

Leprieur, F., P. Descombes, T. Gaboriau, P. F. Cowman, V. Parravicini, M. Kulbicki, C. J. Melián, C. N. De Santana, C. Heine, and D. Mouillot. 2016. Plate tectonics drive tropical reef biodiversity dynamics. Nature Communications 7:1-8.

Levin, L. A. 2006. Recent progress in understanding larval dispersal: new directions and digressions. Integrative and comparative biology 46:282-297.

Levin, L. A. and T. S. Bridges. 1995. Pattern and diversity in reproduction and development. Ecology of marine invertebrate larvae 1:48. 
Levin, L. A., R. J. Etter, M. A. Rex, A. J. Gooday, C. R. Smith, J. Pineda, C. T. Stuart, R. R. Hessler, and D. Pawson. 2001. Environmental influences on regional deep-sea species diversity. Annual review of ecology and systematics 32:51-93.

Levin, L. A. and J. D. Gage. 1998. Relationships between oxygen, organic matter and the diversity of bathyal macrofauna. Deep Sea Research Part II: Topical Studies in Oceanography 45:129-163.

Malyutina, M. V. and A. Brandt. 2013. Introduction to SoJaBio (Sea of Japan biodiversity studies). Deep Sea Research Part II: Topical Studies in Oceanography 86:1-9.

Malyutina, M. V. and A. Brandt. 2018. First records of deep-sea Munnopsidae (Isopoda: Asellota) from the Kuril Basin of the Sea of Okhotsk, with description of Gurjanopsis kurilensis sp. nov. Deep Sea Research Part II: Topical Studies in Oceanography 154:275291.

McClain, C. R., A. P. Allen, D. P. Tittensor, and M. A. Rex. 2012. Energetics of life on the deep seafloor. Proceedings of the National Academy of Sciences 109:1536615371 .

McEdward, L. 2020. Ecology of marine invertebrate larvae. CRC press.

Mileikovsky, S. 1971. Types of larval development in marine bottom invertebrates, their distribution and ecological significance: a re-evaluation. Marine Biology 10:193-213.

Oksanen, J., F. G. Blanchet, M. Friendly, R. Kindt, P. Legendre, D. McGlinn, P. Minchin, R. O’Hara, G. Simpson, and P. Solymos. 2019. vegan: Community Ecology Package (R package Version 2.5-5) https:// CRAN.R-project.org/package=vegan. Community ecology package.

Ostenso, N. A. 1962. Geophysical investigations of the Arctic Ocean basin. The University of Wisconsin-Madison.

Pebesma, E. 2018. Simple features for R: Standardized support for spatial vector data, R J., 10, 439-446.

Pechenik, J. A. 1999. On the advantages and disadvantages of larval stages in benthic marine invertebrate life cycles. Marine Ecology Progress Series 177:269-297.

Provoost, P. and S. Bosch. 2020. robis: Ocean Biodiversity Information System (OBIS) Client. .

Read, G. and K. Fauchald. 2020. World polychaeta database. Pseudopotamilla laciniosa.

Renema, W., D. R. Bellwood, J. C. Braga, K. Bromfield, R. Hall, K. G. Johnson, P. Lunt, C. P. Meyer, L. B. McMonagle, R. J. Morley, A. O’Dea, J. A. Todd, F. P. Wesselingh, M. E. J. Wilson, and J. M. Pandolfi.
2008. Hopping Hotspots: Global Shifts in Marine Biodiversity. Science (New York, N.Y.) 321:654-657.

Rex, M. A., J. A. Crame, C. T. Stuart, and A. Clarke. 2005. Large-scale biogeographic patterns in marine mollusks: A confluence of history and productivity? Ecology 86:2288-2297.

Rex, M. A., C. T. Stuart, and G. Coyne. 2000. Latitudinal gradients of species richness in the deep-sea benthos of the North Atlantic. Proceedings of the National Academy of Sciences of the United States of America 97:4082-4085.

Roberts, C. M., C. J. McClean, J. E. Veron, J. P. Hawkins, G. R. Allen, D. E. McAllister, C. G. Mittermeier, F. W. Schueler, M. Spalding, and F. Wells. 2002. Marine biodiversity hotspots and conservation priorities for tropical reefs. Science (New York, N.Y.) 295:12801284.

Saeedi, H., Z. Basher, and M. J. Costello. 2017a. Modelling present and future global distributions of razor clams (Bivalvia: Solenidae). Helgoland Marine Research 70:23.

Saeedi, H., A. F. Bernardino, M. Shimabukuro, G. Falchetto, and P. Y. G. Sumida. 2019a. Macrofaunal community structure and biodiversity patterns based on a wood-fall experiment in the deep South-west Atlantic. Deep Sea Research Part I: Oceanographic Research Papers.

Saeedi, H. and A. Brandt. 2020a. Biogeographic Atlas of the Deep NW Pacific Fauna. Advanced Books 1.

Saeedi, H. and A. Brandt. 2020b. NW Pacific Deep-sea Benthos Biodiversity (Beneficial Project), v1.2. Deep-sea OBIS node. Dataset/Samplingevent.

Saeedi, H. and M. Costello. 2012. Aspects of global distribution of six marine bivalve mollusc families. Clam fisheries and aquaculture:27-44.

Saeedi, H. and M. J. Costello. 2019. A world dataset on the geographic distributions of Solenidae razor clams (Mollusca: Bivalvia). Biodiversity Data Journal 7.

Saeedi, H., M. J. Costello, D. Warren, and A. Brandt. 2019b. Latitudinal and bathymetrical species richness patterns in the NW Pacific and adjacent Arctic Ocean. Scientific Reports 9:9303.

Saeedi, H., T. E. Dennis, and M. J. Costello. 2017b. Bimodal latitudinal species richness and high endemicity of razor clams (Mollusca). Journal of Biogeography 44:592-604.

Saeedi, H., J. D. Reimer, M. I. Brandt, P.-O. Dumais, A. M. Jażdżewska, N. W. Jeffery, P. M. Thielen, and M. J. Costello. 2019c. Global marine biodiversity in the context of achieving the Aichi Targets: ways forward and addressing data gaps. PeerJ 7:e7221. 
Saeedi, H., M. Simões, and A. Brandt. 2019d. Endemicity and community composition of marine species along the NW Pacific and the adjacent Arctic Ocean. Progress in Oceanography 178:102199.

Saeedi, H., M. Simões, and A. Brandt. 2020. Biodiversity and distribution patterns of deep-sea fauna along the temperate NW Pacific. Progress in Oceanography 183:102296.

Saeedi, H., D. Warren, and A. Brandt. in press. The environmental drivers of benthic fauna diversity and community composition. Frontiers in Marine Science.

Saeedi, H., Winterberg H, Alalykina LI, Bergmeier SF, Downey R, Golovan O, Jażdżewska A, kamenev G, kameneva N, Maiorova A, Malyutina M, Minin K, Mordukhovich V, Petrunina A, Schwabe E, and B. A. 2019e. NW pacific deep-sea benthos distribution and abundance (Beneficial Project). Deep-sea OBIS node. Dataset/Samplingevent 1.

Sakshaug, E. 2004. Primary and secondary production in the Arctic Seas. Pp. 57-81. The organic carbon cycle in the Arctic Ocean. Springer.

Shanks, A. L. 2009. Pelagic larval duration and dispersal distance revisited. The Biological bulletin 216:373385.

Siegel, D., B. Kinlan, B. Gaylord, and S. Gaines. 2003. Lagrangian descriptions of marine larval dispersion. Marine Ecology Progress Series 260:83-96.

Simões, M. V., H. Saeedi, M. E. Cobos, and A. Brandt. 2021. Environmental matching reveals non-uniform range-shift patterns in benthic marine Crustacea. Climatic Change 168:1-20.

Sirenko, B. I. 2001. List of species of free-living invertebrates of Eurasian Arctic seas and adjacent deep waters. Russian Academy of Science, Zoological Institute.

Spalding, M. D., H. E. Fox, G. R. Allen, N. Davidson, Z. A. Ferdana, M. Finlayson, B. S. Halpern, M. A. Jorge, A. Lombana, and S. A. Lourie. 2007. Marine ecoregions of the world: a bioregionalization of coastal and shelf areas. BioScience 57:573-583.

Springer, A. M. and C. P. McRoY. 1993. The paradox of pelagic food webs in the northern Bering Sea-III. Patterns of primary production. Continental Shelf Research 13:575-599.

Suzuki, R. and H. Shimodaira. 2019. pvclust: hierarchical clustering with $\mathrm{p}$-values via multiscale bootstrap resampling. R package version 2.2-0. The R Foundation. Vienna.

Talmage, S. C. and C. J. Gobler. 2011. Effects of Elevated Temperature and Carbon Dioxide on the Growth and Survival of Larvae and Juveniles of Three Species of Northwest Atlantic Bivalves. Plos One 6.
Thorrold, S. R., G. P. Jones, M. E. Hellberg, R. S. Burton, S. E. Swearer, J. E. Neigel, S. G. Morgan, and R. R. Warner. 2002. Quantifying larval retention and connectivity in marine populations with artificial and natural markers. Bulletin of Marine Science 70:291-308.

Tittensor, D. P., C. Mora, W. Jetz, H. K. Lotze, D. Ricard, E. V. Berghe, and B. Worm. 2010. Global patterns and predictors of marine biodiversity across taxa. Nature 466:1098.

Valentine, J. W. and D. Jablonski. 2015. A twofold role for global energy gradients in marine biodiversity trends. Journal of Biogeography 42:997-1005.

Verween, A., M. Vincx, and S. Degraer. 2007. The effect of temperature and salinity on the survival of Mytilopsis leucophaeata larvae (Mollusca, Bivalvia): The search for environmental limits. Journal of Experimental Marine Biology and Ecology 348:111-120.

Wägele, J.-W. 1989. Evolution und phylogenetisches System der Isopoda.

Westheide, W. and R. Rieger. 1996. Spezielle Zoologie, Teil 1: Einzeller und Wirbellose. Gustav Fischer Verlag, Jena, New York [in German].

Wickham, H. 2016. ggplot2: elegant graphics for data analysis. Springer.

Wickham, H., J. Bryan, M. Kalicinski, K. Valery, C. Leitienne, B. Colbert, D. Hoerl, E. Miller, and M. J. Bryan. 2019. Package 'readxl'.

Wickham, H., R. François, and L. Henry. 2021. Müller K. dplyr: a grammar of data manipulation. 2020. R package version 0.84 .

Wickham, H. and L. Henry. 2020. Tidyr: Tidy messy data. R package version 1:397.

Wilson, W. H. 1991. Sexual reproductive modes in polychaetes: classification and diversity. Bulletin of Marine Science 48:500-516.

Woodgate, R. A. and K. Aagaard. 2005. Revising the Bering Strait freshwater flux into the Arctic Ocean. Geophysical Research Letters 32.

Woolley, S. N., D. P. Tittensor, P. K. Dunstan, G. Guillera-Arroita, J. J. Lahoz-Monfort, B. A. Wintle, B. Worm, and T. D. O'hara. 2016. Deep-sea diversity patterns are shaped by energy availability. Nature 533:393.

Yasuhara, M. and R. Danovaro. 2016. Temperature impacts on deep-sea biodiversity. Biological Reviews 91:275-287.

Yasuhara, M., G. Hunt, H. J. Dowsett, M. M. Robinson, and D. K. Stoll. 2012. Latitudinal species diversity gradient of marine zooplankton for the last three million years. Ecology Letters 15:1174-1179.

Zenkevitch, L. 1966. The systematics and distribution of abyssal and hadal (ultraabyssal) Echiuroidea. Galathea report 8:175-184. 